\title{
KETERAMPILAN MENULIS CERPEN DENGAN MENGGUNAKAN MEDIA AUDIO-VISUAL
}

\author{
Nurhidayati $^{1)}$, Rahmawati $^{2)}$, Pitriani $^{3)}$, Salwiah Irwan $^{4)}$ \\ ${ }^{1,2,3,4)}$ Program Studi Pendidikan Bahasa dan Sastra Indonesia \\ Fakultas Sastra, Universitas Muslim Indonesia \\ Email: nurhidayatiam98@gmail.com
}

\begin{abstract}
Abstrak
Keterampilan menulis merupakan salah satu aspek dari keterampilan berbahasa yang tergolong produktif dan kompleks. Maka dari itu, baik dari golongan masyarakat maupun golongan pelajar, dituntut untuk mampu memiliki keterampilan ini. Namun, di lingkup institusional, justru minim ditemukan siswa yang mampu untuk menulis, terlebih minat yang dimiliki siswa pada bidang tersebut sangat rendah dan nyaris menghilang. Menulis selalu berada pada asumsi yang menjemukan dengan tingkat kesulitan yang tinggi. Padahal pentingnya kemampuan menulis yang dimiliki oleh seorang siswa, akan lebih menunjang masa depannya. Namun, karena adanya kekurangmampuan tersebut menjadi penghambat dalam peningkatan keterampilan menulis. Hambatan-hambatan tersebut lahir karena kondisi kelas, dalam hal ini proses belajar-mengajar yang rancu. Tentunya, yang menjadi titik utama dalam hal ini adalah tingkat kekreativitasan pendidik dalam meyampaikan materi di kelas. Para pendidik umumnya hanya memberi teori-teori mengenai cara menulis yang baik dan benar tetapi mengosongkan praktik maupun pengimplementasiannya. Dalam hal ini, porsi antara teori tidak seimbang dengan praktiknya. Jadi, untuk meminimalisirkan hambatan tersebut, diperlukan beberapa inovasi dalam pemilihan media pembelajaran yang lebih kreatif dan relevan dengan mata pelajaran yang hendak disampaikan. Salah satu media yang dianggap cocok dengan materi menulis cerpen adalah media pembelajaran audio-visual. Sifanya yang kompleks akan memudahkan siswa untuk memahami cara menulis yang baik, meningkatkan imajinasi siswa, serta menuntun siswa berpikir kritis, analitis, dan sistematis.
\end{abstract}

Kata kunci: Keterampilan menulis, cerpen, media audio-visual

\section{PENDAHULUAN}

Memasuki era yang sangat maju ini kadangkala membuat masyarakat menanggalkan satu persatu kebiasaan, budaya, bahkan bahasanya sendiri yang sudah dianggap usang dan tergolong tidak mampu menaikkan nama dan popularitasnya di kalangan masyarakat modern. Terlepas dari hal tersebut, dalam dunia pendidikan, meskipun pembelajaran Bahasa Indonesia sudah dipandang sebelah mata namun, mata pelajaran tersebut masih memiliki kedudukan yang penting pada Ujian Nasional dan ujian-ujian formal lainnya. Hal ini terbukti sebab, tujuan dari pembelajaran Bahasa Indonesia adalah agar siswa memiliki kemampuan berbahasa Indonesia yang baik dan benar, dapat menghayati bahasa dan sastra Indonesia sesuai dengan situasi dan tujuan berbahasa, serta tingkat pengalaman siswa di sekolah (Akhadiah dkk, 1991:1).

Mengorek tentang mata pelajaran Bahasa Indonesia, berarti menyembulkan beberapa aspek keterampilan yang menjadi kenamaan dalam pelajaran tersebut. Aspek keterampilan yang dimaksud yaitu keterampilan menyimak, keterampilan berbicara, keterampilan membaca, dan keterampilan menulis. Keempat keterampilan tersebut memiliki kaitan satu sama lain dan manfaat yang sangat 
penting. Salah satunya yakni keterampilan menulis. Alih-alih keterampilan lainnya, keterampilan menulis merupakan keterampilan yang sangat produktif sebab menulis adalah kegiatan yang mampu menghasilkan suatu tulisan berupa karya fiksi maupun non-fiksi.

Gegne menyatakan bahwa menulis sebagai kegiatan tertinggi karena keterampilan menulis merupakan keterampilan kognitif (memahami, mengetahui, mempersepsi) yang kompleks yang menghendaki strategi kognitif yang tepat, keterampilan intelektual, informasi verbal dan motivasi yang tepat. Demikianlah menulis dikatakan sebagai suatu proses yang kompleks karena selain peserta didik harus memiliki kemampuan imajinasi yang tinggi, perbendaharaan kata yang luas, pemahaman tentang pemakaian tanda baca, peserta didik harus menguasai tataran ilmu linguistik umum (fonologi, morfologi, sintaksis, dan semantik).

Menulis memiliki peran yang sangat penting dalam kehidupan bermasyrakat. Bukan sekadar pendongkrak popularitas, namun menulis merupakan sarana bagi masyarakat untuk saling mengingatkan satu sama lain. Sebab, dalam tulisan penulis menyisipkan sejumlah pesan moral, maupun pengetahuan untuk dibagi kepada para pembaca.

Berdasarkan pemaparan di atas, jelas bahwa keterampilan menulis memberikan efek positif di kalangan peserta didik. Menambah wawasan, memberikan pengalaman, dan pola pikir yang terstruktur adalah suatu janji dari kebiasaan menulis yang diterapkan. Namun dewasa ini, menulis adalah kegiatan yang hampir punah di kalangan masyarakat, terlebih pada lingkup sekolah. Para pendidik umumnya hanya memberi teori-teori mengenai cara menulis yang baik dan benar tetapi mengosongkan praktik maupun pengimplementasiannya. Dalam hal ini porsi antara teori tidak seimbang dengan praktiknya. Hal serupa ini terjadi ketika para pendidik memberikan pengajaran Bahasa Indonesia, terlebih pada keterampilan menulis, guru menggunakan cara yang konvensional untuk menyampaikan isi pembelajaran. Hal inilah yang menjadi pemicu kesenjangan menulis pada peserta didik. Jadi, bukan hal yang tabu lagi apabila menemui fakta bahwa produksi buku negara-negara setiap tahunnya, Indonesia berada pada urutan yang rendah.

Mirisnya keadaan literasi di jenjang pendidikan yang ada di Indonesia sekarang, mendorong para pendidik melakukan inovasi dalam proses pembelajaran. Salah satunya kreatif dalam memilih media pembelajaran yang relevan dengan materi menulis yang akan disampaikan namun unik.

Media adalah setiap orang, bahan alat, atau peristiwa yang dapat menciptakan kondisi yang memungkinkan pembelajar untuk menerima pegetahuan, keterampilan dan sikap (anitah, 2008:11). Berdasarkan asumsi tersebut, media yang kreatif mampu menjadi motivasi dan menumbuhkembangkan minat siswa dalam menulis. Salah satu media yang relevan dalam menyampaikan pembelajaran menulis adalah media audio-visual. Media audio-visual dikenal sebagai media perantara atau penggunaan materi dan penyerapannya melalui pandangan dan pendengaran sehingga membangun kondisi yang dapat membuat siswa mampu memperoleh pengetahuan, keterampilan dan sikap.

Oleh karena itu, adanya tindakan berlanjut yang dilakukan oleh pendidik 
sekarang dengan mengadakan inovasiinovasi dalam pembelajaran menulis, diharapkan mampu memberi hasil yang memuaskan. Sebab, yang menjadi penilaian penting untuk seorang guru adalah kemampuan mentransfer sebuah pengetahuan, bukan pengetahuan yang mengendap.

\section{PEMBAHASAN}

\section{Keterampilan Menulis}

Menulis pada hakikatnya adalah suatu proses berpikir yang teratur, sehingga apa yang ditulis mudah dipahami pembaca. Menulis adalah membuat huruf, angka, dan sebagainya dengan pena, pensil, cat, dan sebagainya melahirkan pikiran atau perasaan seperti mengarang, membuat surat, dan sebagainya dengan tulisan. Definisi lain dari menulis juga dikemukakan oleh Syafi'i (1998:45) yang berbunyi, menulis adalah menuangkan gagasan, pendapat, perasaan, keinginan, dan kemauan, serta informasi ke dalam tulisan dan kemudian "mengirimkannya" kepada orang lain. Sebuah tulisan dikatakan baik apabila memiliki ciri-ciri, antara lain bermakna jelas, bulat, dan utuh, dan memenuhi kaidah gramatikal. Menulis menggunakan bahasa sebagai perantara. Semakin teratur bahasa yang digunakan, semakin mudah pembaca menangkap apa yang ingin disampaikan.

Seiring dengan perkembangan teknologi dan media, kegiatan menulis juga ikut berkembang pesat di dunia. Melalui media elektronik, setiap orang dapat memperoleh bahan penulisan dari internet, sehingga penulis lebih efisien waktu, biaya, dan tenaga. Saat ini penulis juga bisa berbagi tulisan di manapun ia berada dengan menggunakan teknologi berbasis internet. Begitu juga dengan para pembaca, akan lebih mudah untuk melihat tulisan-tulisan penulis yang digemarinya.

Sekaitan dengan hal di atas, kegiatan menulis tidak lepas dari keterampilan yang dimiliki oleh penulis. Keterampilan menulis sangat dibutuhkan dalam kehidupan. Menulis telah menjadi gaya dan pilihan untuk mengaktualisasikan diri, alat untuk membebaskan diri dari berbagai tekanan emosional, sarana membangun rasa percaya diri dan sarana untuk berkreasi dan rekreasi. Seseorang tergerak menulis karena memiliki tujuantujuan yang bisa dipertanggungjawabkan di hadapan pembacanya, karena tulisan pada dasarnya adalah sarana untuk menyampaikan pendapat, atau gagasan agar dapat dipahami dan diterima orang lain.

\section{Keterampilan Menulis Cerpen}

Menulis merupakan salah satu keterampilan berbahasa yang sangat penting diajarkan di sekolah sejak dini. Hal ini disebabkan dari keempat keterampilan berbahasa yang dimiliki seseorang, keterampilan menulis mampu membuat seseorang tidak hanya berkomunikasi dengan orang-orang yang ada di sekelilingnya tetapi juga memungkinkan untuk berkomunikasi dengan orang-orang yang terpisah oleh ruang dan waktu. Keterampilan menulis bukan keterampilan yang sulit tetapi juga tidak mudah untuk dilakukan. Seseorang harus berlatih berulang-ulang secara tekun dan memerlukan waktu yang tidak sedikit untuk memperoleh keterampilan menulis yang baik dan benar. Melalui kegiatan menulis, terutama dalam dunia pendidikan diharapkan siswa dapat menuangkan ideide atau gagasan-gagasan kreatif baik yang bersifat ilmiah maupun imajinatif. 
Secara spesifik, Umar Mansyur (2016) menjelaskan bahwa pembelajaran sastra di sekolah, khususnya cerpen, bertujuan untuk menanamkan, menumbuhkan dan mengembangkan kepekaan kepada siswa terhadap masalahmasalah dunia, pengenalan dan rasa hormat terhadap tata nilai, baik dalam konteks individu maupun sosial, yang kesemuanya itu sangat relevan dengan muatan yang terdapat dalam kurikulum pendidikan karakter saat ini. Melalui pembelajaran cerpen, siswa dapat lebih tanggap dalam konteks pembelajaran apapun, dan juga dapat lebih tanggap dalam kehidupan sosialnya.

Sebagian siswa beranggapan bahwa menulis merupakan suatu kegiatan yang membosankan dan menjenuhkan. Oleh karena itu, guru dituntut kreatif dalam menerapkan metode pendekatan ataupun penggunaan media dalam meningkatkan minat dan keterampilan menulis siswa sehingga tidak merasa jenuh atau bosan. Dan salah satu kegiatan dari keterampilan menulis adalah menulis cerpen atau cerita pendek yang merupakan suatu bentuk prosa naratif fiktif. Cerita pendek cenderung padat dan langsung pada tujuannya dibandingkan karya-karya fiksi lain yang lebih panjang, seperti novel.

Sebelum memulai sebuah tulisan seorang penulis perlu mengetahui tujuan dari menulis itu sendiri. Karena seseorang akan tergerak menulis ketika telah mengetahui tujuan-tujuan menulis. Oleh karena itu, adapun tujuan-tujuan penulisan tersebut adalah sebagai berikut:

1. Informasi, menginformasikan segala sesuatu, baik itu fakta, data maupun peristiwa termasuk pendapat dan pandangan terhadap fakta, data dan peristiwa.
2. Membujuk, melalui tulisan seorang penulis mengharapkan pembaca dapat menentukan sikap, apakah menyetujui atau mendukung hal yang dikemukakan dengan menggunakan gaya bahasa yang persuasif atau gaya bahasa yang menarik, akrab, bersahabat, dan mudah dicerna.

3. Mendidik, mendidik adalah salah satu tujuan komunikasi melalui tulisan. Melalui membaca hasil tulisan wawasan pengetahuan seseorang akan terus bertambah.

4. Menghibur, fungsi dan tujuan menghibur dalam komunikasi, bukan monopoli media massa, radio, televisi, namun media cetak dapat pula berperan dalam menghibur khalayak pembacanya, seperti anekdot, dan cerita pengalaman lucu bisa pula menjadi bacaan penghibur lara atau melepaskan ketegangan dan kepenatan setelah seharian sibuk beraktivitas.

Keterampilan menulis cerpen merupakan proses belajar yang memerlukan proses berlatih, secara berkelanjutan. Keterampilan menulis cerpen tentu akan meningkat seiring dengan pembinaan yang tepat dan terencana. Akan tetapi, dalam menulis cerpen siswa masih kesulitan, dalam mengembangkan ide/gagasan yang berakibat tidak berhasilnya siswa dalam membuat cerpen. Kesulitan dalam meningkatkan keterampilan menulis cerpen pada siswa patut mendapat perhatian yang cukup banyak dari guru sebagai tenaga pengajar. Dengan demikian, penerapan suatu teknik metode, dan media yang tepat sebagai solusi yang efektif mutlak diperlukan.

Penggunaan metode dan media pembelajaran bergantung pada tujuan yang ingin dicapai dalam pembelajaran. Setiap 
materi pembelajaran yang hendak disampaikan mempunyai karakteristik tersendiri. Metode yang digunakan juga harus tepat sesuai dengan materi pembelajarannya. Begitu juga dengan pembelajaran menulis, guru harus bisa memilih dan menggunakan metode yang sesuai dengan materi yang diajarkan pada siswa. Guru yang mengetahui aneka ragam teknik pengajaran keterampilan menulis cerpen dan dapat mempraktikkannya akan sangat membantu siswa dalam mengajarkan keterampilan menulis cerpen. Setelah menentukan metode dan teknik, maka langkah selanjutnya adalah pemilihan media pembelajaran. Semakin kreatif media yang digunakan, maka semakin besarkemungkinan siswa dan guru mencapai tujuan dari pembelajaran.

Berdasarkan uraian di atas, metode, teknik dan media memiliki keterkaitan satu sama lain dalam mencapai keberhasilan proses belajar-mengajar. Pemilihan Metode, teknik, dan media pengajaran yang tepat, termasuk pengajaran keterampilan menulis cerpen, memberikan keuntungan bagi pelaksanaan proses belajar mengajar.

Suasana yang menarik, merangsang, menimbulkan minat belajar yang tinggi. Minat belajar yang tinggi dapat menimbulkan prestasi belajar yang tinggi pula. Oleh karena itu sebelum seseorang ingin menulis, maka yang perlu diperhatikan oleh seorang penulis dalam menulis adalah tahap-tahap penulisan dimana pada tahap ini, dilakukan pengembangan gagasan ataupun butir-butir pokok yang telah dibuat sebelumnya. Setiap subpokok dikembangkan menjadi paragaraf. Semakin jelas ide pokok yang terdapat dalam paragraf tersebut, maka akan membangun sebuah paragraf.
Secara umum tahap-tahap dalam menulis terdiri atas tahap pramenulis, tahap perencanaan tulisan, tahap penulisan, tahap revisi dan tahap publikasi.

\section{Tahap Pra-menulis}

Tahap ini merupakan tahap persiapan. Ada dua kegiatan yang dilakukan pada tahap ini. Pertama, menulis topik dan selanjutnya menentukan tujuan. Penentuan tujuan ini berkaitan dengan pemelihan bentuk karangan. Bentuk karangan ini bisa berupa narasi, deskripsi, eksposisi, argumentasi, dan persuasi. Tahap pertama berupa penentuan topik. Topik dapat diperoleh dari berbagai sumber, seperti koran, televisi, maupun pengalaman penulis sendiri. Misalnya topik dari berita di televisi tentang kenaikan harga BBM.

\section{Tahap Perencanaan Tulisan}

Perencanaan penulisan berkaitan dengan penyusunan kerangka tulisan. Kerangka harus disusun secara sistematis (Akhadiah, 1998:5). Pada tahap rencana ini penulis sudah memulai dengan menbuat konsep awal sebuah tulisan. Konsep awal dalam hal ini berupa garis-garis besar setiap informasi yang akan ditulis. Caranya dengan mencatat segala informasi yang akan tulis dalam sebuah kertas. Hal ini untuk menghindari informasi yang tumpang tindih.

\section{Tahap Penulisan}

Pada tahap ini, dilakukan pengembangan gagasan ataupun butir-butir pokok yang telah dibuat sebelumnya. Setiap subpokok dikembangkan menjadi sebuah paragraf. Semua informasi yang diperoleh ditulis dengan rinci dalam tahap ini. Laksana (2007) menyatakan bahwa penulis tidak seharusnya melakukan pekerjaan menulis dan merevisi. Sekaligus karena akan memperlambat proses 
penilaian. Ini berarti bahwa tahap menulis dan merevisi letaknya terpisah. Revisi dilakukan setelah penulis selesai menulis draf.

\section{Tahap Revisi}

Revisi adalah pemeriksaan terhadap tulisan yang telah dibuat. (Akhadiah, 1998:5). Revisi diperlukan untuk menghasilkan tulisan yang baik. Pada tahap ini penulis secara menyeluruh mengoreksi tentang bahasa, struktur karangan, ejaan, tanda baca, pilihan kata, dan kaidah gramatikal. Dalam hal ini penliti benar-benar harus meneliti tulisannya.

\section{Tahap Publikasi}

Tahap ini merupakan tahap yang terakhir. Publikasi dapat dilakukan dengan menyampaikan tulisan yang telah dibuat kepada khalayak ramai. Publikasi diperlukan agar orang lain tahu informasi yang ingin disampaikan oleh penulis. Di sinilah akan terjadi komunikasi antara penulis dan pembaca. Tulisan yang dimuat di surat kabar adalah salah satu contoh publikasi tulisan.

\section{Media Pembelajaran}

Kata media berasal dari Bahasa Latin yang merupakan bentuk jamak dari kata medium yang secara harfiah berarti "perantara" atau "pengantar" (Arif S., Sadiman, dkk, 2006:6). Jadi secara bahasa media berarti pengantar pesan dari pengirim kepada penerima pesan. Secara khusus, pengenalan media dalam proses belajar mengajar mendorong diartikan sebagai alat-alat grafis, fotografis, atau elektronis untuk menangkap, memproses, dan menyusun kembali informasi visual atau verbal (Ashar Arsyad, 1996:3).

Sementara itu, menurut Anderson, media pembelajaran adalah media yang memungkinkan terwujudnya hubungan langsung antara karya seseorang pengembang mata pelajaran dengan para siswa.

Berdasarkan pendapat di atas, dapat disimpulkan definisi dari media pembelajaran adalah suatu alat yang dapat dilihat, didengar, dibaca atau dibicarakan yang disampaikan oleh pengirim ke penerima sehingga mampu merangsang pikiran, perhatian, minat penerima sehingga terjadilah proses belajar yang efektif. Dalam hal ini peran guru dalam menggunakan media pembelajaran ketika proses pembelajaran berlangsung sangat penting. Sebab, media pembelajaran adalah salah satu alat yang mampu mempermudah guru dalam penyampaian materi secara kreatif serta dengan adanya media pembelajaran memungkinkan terciptanya suasan kelas yang kondusif.

Menurut Azhar Arsyad, media pembelajaran memiliki ciri-ciri umum, yakni sebagai berikut:

1. Media pembelajaran memiliki pengertian fisik yang dikenal sebagai hardware (perangkat keras) yaitu sesuatu benda yang dapat dilihat, didengar, atau diraba dengan pancaindra.

2. Media pembelajaran memiliki pengertian non fisik yang dikenal sebagai software (perangkat lunak), yaitu kandungan pesan yang terdapat dalam perangkat kerasa yang merupakan isi yang ingin disampaikan kepada peserta didik.

3. Penekanan media pembelajaran terdapat pada visual dan audio.

4. Media pembelajaran memiliki pengertian sebagai laat bantu pada proses belajar, baik di dalam maupun di luar kelas. 
5. Media pembelajaran digunakan dalam rangka komunikasi dan interaksi guru dan peserta didik dalam proses pembelajaran.

6. Media pembelajaran dapat digunakan secara massal, kelompok besar, kelompok kecil, dan perorangan.

Menurut Levied dan Lentz (dalam Arsyad, 2005:16-17), khususnya media visual, mengemukakan bahwa media pembelajaran memiliki empat fungsi, yaitu fungsi atensi, fungsi afektif, fungsi kognitif, dan fungsi kompensatoris. Kalisifikasi dari fungsi di atas, dijelaskan di bawah ini:

1. Fungsi atensi media visual meupakan inti, yaitu menarik dan mengarahkan perhatian peserta didik untuk berkonsentrasi terhadap isi pelajaran yang berkaitan dnegan makna visual yang ditampilkan atau menyertai teks mata pelajaran.

2. Fungsi afektif media visual dapat terlihat dari tingkat kenikmatan peserta didik ketika belajar atau membaca teks yang bergambar. Gambar atau lambing visual dapat menggugah emosi dan sikap peserta didik.

3. Fungsi kognitif media visual terlihat dari temuan visual atau gambar memperlancar pencapaian tujuan untuk memahami dan mengingat informasi atau pesan yang terkandung dalam gambar.

4. Fungsi kompensatoris media pembelajaran terlihat dari hasil penelitian bahwa media visual yang memberikan konteks untuk memahami teks membantu peserta didik yang lemah dalam membaca untuk mengorganisasikan informasi dalam teks dan mengingatnya kembali.

Berdasarkan fungsi di atas, media memiliki fungsi umum yaitu untuk tujuan intruksi di mana informasi yang terdapat dalam media itu harus melibatkan peserta didik, baik dalam benak atau mental maupun dalam aktivitas yang nyata sehingga dapat terjadi.

Maraknya penggunaan media pembelajaran di lembaga pendidikan, memberikan umpan balik positif terhadap guru dan siswanya. Hal ini dilandasi atas beberapa kegunaan yang kemudian menjadi tolak ukur guru dalam penggunaannya. Dalam hal ini, guru akan lebih mudah mentransfer materi yang akan disampaikan melalui medi pembelajaran yang telah dipilih, dan siswa akan lebih mudah memahami materi yang disampaikan. Secara terperinci, di bawah ini dijelaskan kegunaan dari media pembelajaran, yakni sebahgai berikut:

1. Media pembelajaran dapat memperjelas penyajian peran dan informasi sehingga dapat memperlancar dan meningkatkan proses dan hasil belajar.

2. Media pembelajaran dapat meningkatkan dan mengarahkan perhatian anak sehingga dapat meningkatkan motivasi belajar, interaksi yang lebih langsung antara peserta didik dan lingkungannya dan kemungkinan peserta didik untuk belajar sendiri-sendiri berdasarkan kemampuan dan minatnya.

3. Media pembelajaran dapat mengatasi keterbatasan indra, ruang, dan waktu.

\section{Media Pembelajaran Audiovisual dalam Pembelajaran Cerpen}

Media pembelajaran audio-visual merupakan bagian dari jenis-jenis media pembelajaran yang menggabungkan dua media auditif yaitu media audio (suara) dengan media visual (gambar). Oleh karena hal tersebut, audio-visual dikatakan media pembelajaran yang lebih baik dari media lainnya. 
Terkait hal di atas, media audiovisual dapat diartikan sebagai media yang digunakan untuk menyampaikan pesan pembelajaran. Adanya unsur audio memungkinkan siswa untuk dapat menerima pesan pembelajaran melalui pendengaran, sedangkan unsur visual memungkinkan penciptaan pesan belajar melalui bentuk visualisasi.

Ditinjau dari segi keadaannya, media audio-visual dibagi menjadi dua, yaitu audio-visual murni dan audio-visual tidak murni. Adapun perinciannya adalah sebagai berikut:

1. Audio-Visual Murni, atau sering disebut dengan audio-visual gerak adalah media yang dapat menampilkan unsur suara dan gambar yang bergerak, unsur suara maupun unsur gambar tersebut berasal dari suatu sumber. Contoh: film bersuara, video, dan televisi.

2. Audio-visual tidak murni, yaitu media yang unsur suara dan gambarnya berasal dari sumber yang berbeda. Audio visual tidak murni ini sering disebut juga dengan audio visual diam plus suara yaitu media yang menampilkan suara dan gambar. Contoh: sound slide (film bingkai suara)

Pengajaran melalui audio-visual jelas bercirikan pemakaian perangkat keras selam proses pembelajaran seperti mesin proyektor film, tape recorder, dan proyektor visual yang lebar. Ciri-ciri utama teknologi media audio-visual adalah sebagai berikut:

1. Biasanya bersifat linear;

2. Biasanya menyajikan visual yang dinamis;

3. Digunakan dengan cara yang telah di tetapkan sebelumnya oleh perancang/ pembuatnya;

4. Representasi fisik dari gagasan real atau gagasan abstrak;
5. Dikembangkan menurut prinsip psikologis behafiorisme dan kognitif;

6. Umumnya berorientasi kepada guru dengan tingkat pelibatan pembelajaran aktif murid yang rendah.

Kelebihan media audio-visual yaitu dalam media ini mencakup segala aspek indra pendengar, penglihatan, dan peraba. Sehingga kemampuan semua indra dapat terasa dengan baik karena digunakan dengan seimbang dan bersama. Adapan kelemahan media audio-visual, yaitu keterbatasan biaya serta penerapannya yang harus mampu menccakup segala aspek indra pendengaran, penglihatan,dan peraba.

Setelah mengetahui hal-hal yang berkaitan dengan media pembelajaran audio-visual, rasa-rasanya akan lebih relevan apabila dikaitkan dengan pembelajaran menulis cerpen. Dalam hal ini, media audio-visual akan lebih memudahkan siswa untuk memahami segala pemaknaan yang dipaparkan pada media audio-visual. Sifat audio-visual yang runtut, teratur, dan terorganisir selaras dengan sifat cerpen yang demikian. Siswa akan merasakan secara langsung meskipun sebenarnya tidak mengalami hal-hal yang ditayangkan. Singkatnya, siswa ibarat terjun langsung dalam tayangan yang diputar ketika melihat gambar (visual) dan turut merasakan emosi yang tercipta dari tayangan yang menimbulkan bunyi (sound).

Media audio-visual cukup menarik apabila diterapkan dalam kelas, namun penggunaan media audio-visual dalam pembelajaran memerlukan beberapa persiapan dan perencanaan yang cukup rinci dan matang karena, media ini adalah salah satu senjata guru dalam mengajar. Apabila terjadi sebuah kesalahan karena minimnya persiapan yang dilakukan oleh 
guru, kemungkinan besar tujuan dari pembelajaran akan terhambat. Maka dari itu, ada beberapa hal yang perlu diperhatikan dalam penggunaan media audio-visual, yakni sebagai berikut:

1. Guru harus mempersiapkan unit pelajaran terlebih dahulu kemudian memilih media audio-visual yang relevan dengan materi yang akan diajarkan.

2. Guru harus mengetahui durasi penggunaan media audio-visual.

3. Mempersiapkan kelas, yang meliputi persiapan siswa dengan memberikan penjelasan global tentang isi film, audio, ataupun tayangan televisi.

4. Aktivitas lanjutan, setelah pemutaran film atau video selesai sebaiknya guru melakukan refleksi dan tanya jawab dengan siswa untuk mengatahui tingkat pemahamannnya

\section{PENUTUP}

Menulis merupakan suatu kegiatan penuangan rasa, sarana kreasi dan rekreasi dengan menggunakan berbagai alat tulis atau mesin ketik. Seiring perkembangan zaman, penyebaran dan temuan karya tulis lebih mudah diperoleh di media sosial. Menulis sering dikaitkan dengan kegiatan yang kompleks karena dari proses pembuatannya lebih mengacu kepada cara berpikir yang kritis, analitis, dan sistematis. Maka dari itu, kegiatan menulis memerlukan keterampilan tertentu agar karyanya mampu diterima di kalangan masyarakat dunia.

Keterampilan Menulis cerpen memiliki kedudukan yang penting di bangku pendidikan. Hal ini didukung dari posisinya yang masuk dalam kategori aspek keterampilan berbahasa. Meski demikian, keterampilan menulis adalah suatu kegiatan yang jarang dilirik atau diminati oleh siswa karena dianggap menjenuhkan padahal ditinjau dari segi fungsi dan manfaat, menulis adalah ladang subur bagi siswa kelak. Maka dari itu, untuk menumbuhkan minat dan keterampilan menulis, kekreatifan guru di dalam kelas perlu ditingkatkan. Meningkatkan keterampilan menulis memerlukan frekuensi yang berulang untuk mencapai kemampuan dan keterampilan yang lebih baik.

Media pembelajaran adalah suatu pengantar pesan yang lebih kreatif dalam proses pembelajaran. Semakin baik media yang digunakan, besar kemungkinan siswa berminat dan mudah memahami materi pelajaran. Tentunya hal ini berkaitan dengan tujuan dari media pembelajaran sebagai daya tarik atau alat motivator dalam pembelajaran. Pemilihan media pembelajaran harus relevan dengan materi yang hendak disampaikan, guna mencapai keselarasan, menarik perhatian, sehingga tercapailah tujuan pembelajaran.

Media audio-visual merupakan salah satu media pembelajaran yang kompleks dan lebih baik. Hal ini dikarenakan melibatkan dua unsur auditif yakni audio (suara) dan visual (gambar). Menggunakan media ini dalam kelas akan lebih memacu minat siswa, terlebih ketika digunakan pada pembelajaran menulis cerpen. Sifanya yang kompleks akan memudahkan siswa untuk memahami cara menulis yang baik, meningkatkan imajinasi siswa, serta menuntun siswa berpikir kritis, analitis, dan sistematis. 


\section{DAFTAR PUSTAKA}

Ahmad, Abdul Karim. 2007. Media Pembelajaran. Makassar: Badan Penerbit Universitas Negeri Makassar.

Dalman. 2015. Penulisan Populer. Jakarta: Raja Grafindo Persada.

Diary, Avis's. 2012. Media Audio-Visual, (Online, http://avianinuravivah.blogspot.com/, Diakses 8 Desember 2018).

Dibia, Ketut. 2018. Apresiasi Bahasa dan Sastra Indonesia. Depok: PT Raja Grafindo Persada.

Effendy, Akip. 2012. Hakikat Keterampilan Menulis, (Online, https://www.kompasiana.com/ Diakses 8 Desember 2018).

Mansyur, Umar. 2016. Pemanfaatan Nilai kejujuran dalam Cerpen sebagai Bahan Ajar Berbasis Pendidikan Karakter. In Mengais Karakter dalam Sastra: HISKI Makassar (pp. 330-339). https://doi.org/10.17605/OSF.IO/Z4T3Y.

Mansyur, Umar. 2018. Kiat dan Teknik Penulisan Skripsi bagi Mahasiswa. INA-Rxiv. https://doi.org/10.31227/osf.io/juds7.

Mansyur, Umar. 2018. Korelasi Minat Baca dengan Kemampuan Menulis Karya Tulis Ilmiah Mahasiswa Pendidikan Bahasa Indonesia UMI. Multilingual: Jurnal Kebahasaan dan Kesastraan, 17(1), 11-22.

Sadiman, Arief S., dkk. 2002. Media Pendidikan: Pengertian, Pengembangan, dan Pemanfaatannya (Cetakan Kelima). Jakarta: PT Raja Grafindo Persada.

Suandi, Nengah dkk. 2018. Keterampilan Berbahasa Indonesia Berorientasi Integrasi Nasional dan Harmoni Sosial. Depok: PT Raja Grafindo Persada.

Susanto, Hadi. 2015. Keterampilan Menulis Cerpen. (Online, https://bagawanabiyasa. wordpress.com/ 26 November 2015). 